๑ Ю. С. Ганжуров, д.п.н., професор, НТУУ «КПІ”, Київ, Україна

\title{
АВТОРСЬКЕ ПРАВО У ВИДАВНИЧОМУ ДОГОВОРІ:
} КОНФЛІКТИ ІНТЕРПРЕТАЦІЙ

\section{Розглядаються проблемні зони реалізації авторського права у видавничому договорі. Вивчаються варіативності тлумачення правовідносин автора і видавця в процесі фахової комунікації.}

\section{Ключові слова: авторське право; видавничий договір; передача прав; авторська винагорода.}

Видавничо-поліграфічна галузь традиційно є одним із найпотужніших інформаційних ресурсів втілення нормативноправових засад реалізації авторського права в Україні, багато у чому хрестоматійною базою вивчення природи тих колізій, що виникають в процесі нормативного регулювання правовідносин видавця і автора [1].

Причини, що продукують проблеми реалізації програм захисту об'єктів авторського права, багатьом відомі. Можна, звичайно, посилатись на минулий досвід своєрідного усуспільнення творчих здобутків із огляду на колективістську модель радянського буття. Не буде перебільшенням й твердження про недостатню психологічну, організаційну, професійну толерантність до європейської практики. У межах фахових інтересів вбачається доцільним зосередитись на окремих проблемних питаннях, пов'язаних із авторським правом у видавничій справі, зокрема нормах, випи- саних у Законі України «Про авторське право і суміжні права» (далі - Закон), передусім у частині правовідносин між автором і видавцем. Власне, йдеться про ті проблемні зони, які виникають в результаті конфліктів інтерпретацій норм Закону, покладених у сферу їхньої реалізації. Насамперед йдеться про тлумачення поняття «авторське право». Адже перелік об'єктів, на які поширюється це поняття, не є вичерпним. Відомо, що світова практика не виключає можливість поширення охорони авторського права на видані органами державної влади у межах повноважень офіційні документи політичного, законодавчого, адміністративного характеру. Оскільки в правовому полі функціонує категорія «авторське право на службові твори", яка кореспондується із необхідністю захисту змістової частини нормативно-правових актів, то ця проблема гостро актуалізується саме на рівні видавничої діяльності і часто 


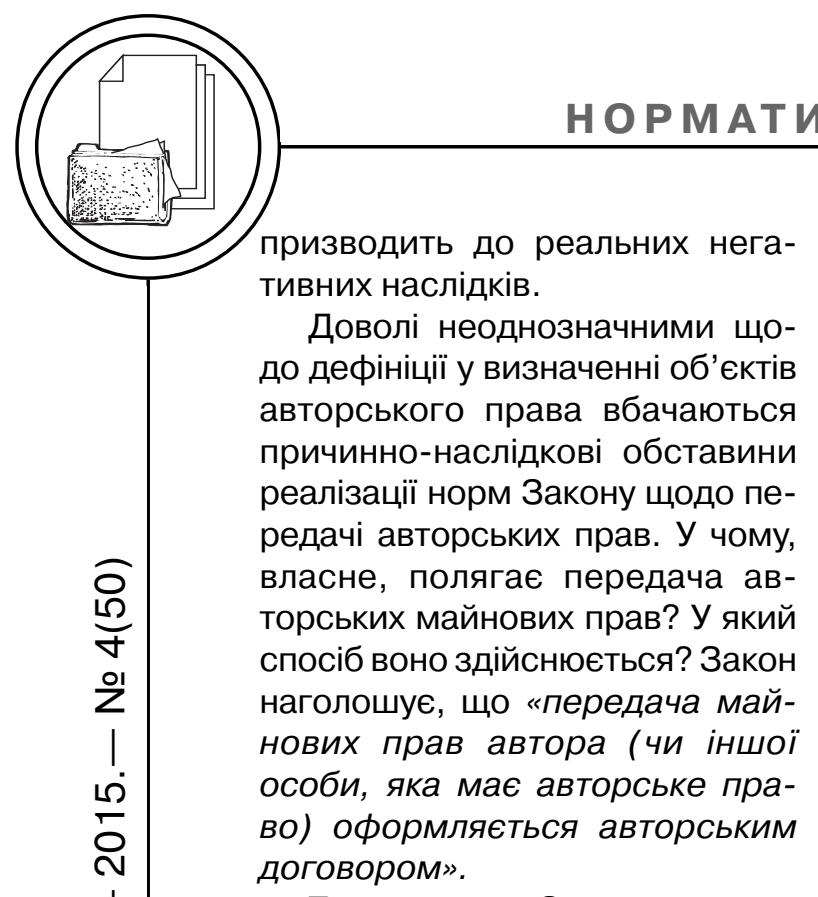

Таким чином, Закон визначає типологію договору (авторський), за яким може здійснюватись передача майнових авторських прав. Підкреслимо: авторський, а не видавничий. Водночас зазначений акт передачі фігурує в іншому документі договорі на право використання творів, які за концептуальним змістом кореспондуються із видавничим договором, який залишається складною зоною реалізації авторських прав [2].

Крім того, вимагає тлумачень норма Закону такого змісту: «B усній формі може укладатися договір про використання (опублікування) твору в періодичних виданнях (газетах, журналах тощо)». Адже зрозуміло: навіть при документуванні усних домовленостей технічними засобами легітимність такої правової основи сумнівна. За таких умов гарантувати автору захист його прав видається проблематичним. Принагідно згадаємо у цьому контексті публікацію інтерв'ю. За Законом, співавторами інтерв'ю є особа, яка дала інтерв'ю, та особа, яка його взяла. Природно, що за таких умов регулювання правовідносин на договірних засадах набуває актуальності. Проте до останнього часу засоби масової комунікації не надають належного значення питанням охорони авторського права. Виняток складають окремі наукові періодичні видання, що позначають публікації знаком охорони авторського права (презумпція авторства).

Відомо, що видавництво, яке $€$ однією стороною договору, може залучити інше видавництво для допомоги у виконанні укладеного договору, письмово повідомивши про це автора. Але воно не може, залишаючись стороною договору, надавати іншим організаціям право видавати даний твір автора, посилаючись на те, що видавництво, а не автор, володіє правом на опублікування, відтворення та розповсюдження творів. Майнові права, що передаються за авторським договором, мають бути у ньому визначені. Майнові права, не зазначені в авторському договорі як відчужувані, вважаються такими, що не передані. Час від часу висловлюються думки про можливість використання творів без дозволу автора. Щоправда, йдеться про фрагментарне використання творів без згоди на це автора (вільне використання твору із зазначенням імені автора). Проте законодавчо межі такого використання не визначені. Тому компіляція є досить поширеним явищем, особливо у навчальній та науковій літературі. Отже, йдеться про 3'ясування правової основи автор- 
ського договору. Важливо наголосити на тому, що суб'єкти авторського права можуть доручати управління своїми майновими правами на колективній основі відповідним державним організаціям, установчі документи яких передбачають здійснення таких функцій. Проте типові видавничі договори подібних правил не виписують. До останнього часу виняток стосувався використання творів вітчизняних авторів за кордоном. Типові видавничі договори включали пункт, який передбачав передачу автором видавництву своїх правочинностей щодо використання зазначеного в договорі твору за кордоном, якщо ці правочинності не були передані раніше іншій організації, про що автор зобов'язаний повідомити видавництво під час укладання договору. У такому разі видавництво представляє інтереси автора у розв'язанні питань стосовно використання його твору за кордоном. При цьому видавництво має вчасно інформувати автора про всі пропозиції, які стосуються використання його твору за кордоном, забезпечити під час укладення договору на використання твору за кордоном охорону особистих прав і майнових інтересів автора, а також можливість внесення в твір необхідних, на думку автора, змін і доповнень. Порівняно недавно серед фахівців з'явилась інша постановка питання, що стосується видавничого договору, яка, по суті, започатковує дискусію про природу авторського договору. Порушується питання про те, що видавничий договір потрібно ви- лучити з галузі авторського права, а предметом правового регулювання видавничого права мають стати взаємовідносини видавництва з авторами (за видавничим договором), з рецензентами, науковими та іншими редакторами, консультантами (за відповідними договорами) та іншими позаштатними учасниками редакційно-видавничого процесу. Можливо, особливий статус матимуть і ті відносини, які складаються між видавництвом і автором замовного рукопису. Таким чином, авторське і видавниче право переходить у площину двох відносно самостійних взаємодіючих інститутів редакційного права. До цієї думки й спонукає тлумачення у фаховій літературі поняття авторського договору про видання (перевидання) твору власне як видавничий договір [3, С. 160]. Відомо, що предметом авторського права $€$ відносини, які складаються у зв'язку зі створенням і використанням творів науки, літератури і мистецтва. Уявімо собі ситуацію, коли відносини, пов'язані 3 відтворенням запатентованими електронними засобами творів науки, літератури і мистецтва, будуть вилучені 3 галузі авторського права та на їх базі утворюватиметься авторське право виробника електронної книги. Оскільки при цьому зберігається інститут авторського права, виникає питання: які ж відносини залишаються предметом його регулювання? Очевидно, що при такому підході авторські відносини повинні бути зведені тільки до закріплення авторства особи, яка створює 
твір, а всі інші відносини, що складаються відносно твору між авторами і організаціями це самостійні предмети інших правових відносин. Таке розв'язання питання недоцільне, особливо в умовах інтеграції України до європейських стандартів, коли немайнові та майнові права автора знаходять всебічну охорону і висуваються на перший план. Якщо в теорії авторського права і в законодавстві видавничий, постановочний, сценарний та інші договори обґрунтовано трактуються як різновиди авторського договору, оскільки у всіх цих договорах відносини складаються між суб'єктом авторських прав (автором або його правонаступником) та організацією (видавництвом) щодо творів науки, літератури або мистецтва, то узагальнюючим родовим поняттям зазначених договорів, у разі звуження сфери дії авторського права, повинен стати договір з надання автору послуг чи інше спрощене визначення цього поняття. Проте для послуги характерна така форма відносин, коли винагорода призначається тому, хто надає послугу, а не отримує їі. Насправді ж, не автор платить, а автору виплачується авторська винагорода і не за надану йому послугу, а за створений ним твір, що $€$ предметом авторського права і переданий організації для використання. На жаль, такі відносини автора і видавця, котрі з'являються на практиці останнім часом, призводять до розкладання авторського права на самостійні інститути правовідносин, кількість яких залежить від існуючих видів використання творів.

Ця обставина певною мірою актуалізує проблему контролю за неухильним додержанням норм законів України, що охороняють авторські та суміжні права. Щоправда, варто визнати проблемність реалізації власне як охорони, так й захисту авторських і суміжних прав у видавничій галузі. Це пов'язано із тим, що поняття «охорона» так само, як й поняття «захист» не мають правового визначення у базовому законі. Такий стан справ актуалізує потребу вдосконалення нормативно-правової бази, що забезпечуватиме недоторканність інтелектуальних ресурсів видавничо-поліграфічної галузі.

\section{Список використаної літератури}

1. Дяченко Ю. П. Видавнича справа : законодавчі засади, нормативне регулювання : Посібник / Ю. П. Дяченко. - К. : Парламентське видавництво, 2006. - 160 с.

2. Афонін О. В. Авторське право у видавничій справі в питаннях й відповідях / О. В. Афонін, О. М. Харченко, У. С. Руденко. - К. : Норма-Друк, 2010. $-80 \mathrm{c}$.

3. Бондаренко С. В. Авторське право і суміжні права / С. В. Бондаренко. - К. : Ін-тут інтел. власн. і права, 2008. - 228 с. 


\section{References}

1. Diachenko lu. P. Vydavnycha sprava : zakonodavchi zasady, normatyvne rehuliuvannia : Posibnyk / lu. P. Diachenko. - K. : Parlamentske vydavnytstvo, 2006. $-160 \mathrm{~s}$.

2. Afonin O. V. Avtorske pravo u vydavnychii spravi v pytanniakh i vidpovidiakh / O. V. Afonin, O. M. Kharchenko, U. S. Rudenko. - K. : Norma-Druk, 2010. $80 \mathrm{~s}$.

3. Bondarenko S. V. Avtorske pravo i sumizhni prava / S. V. Bondarenko. - K. : In-tut intel. vlasn. i prava, 2008. - $228 \mathrm{~s}$.

Рассматриваются проблемные зоны реализации авторского права в издательском договоре. Изучаются вариативности толкования правоотношений автора и издателя в процессе профессиональной коммуникации.

Ключевые слова: авторское право; издательский договор; передача прав; авторское вознаграждение.

Problem areas of copyright implementation in publishing contract are discovered. The variability of interpretation of legal-rational authority between author and publisher in the process of professional communication are studied.

Keywords: copyright; publishing contract; the transfer of rights; royalties.

Рецензент - М. Т. Андрійчук, к.н. із соціальних комунікацій, доцент, НТУУ «КПІ» 